\title{
CITRA DAN STEREOTIP PEREMPUAN SUNDA DALAM NOVEL MARJANAH KARYA S. DJODJOPUSPITO (Kajian Struktural dan Feminisme)
}

\author{
Tsany Nurfajriani \\ MGMP Kabupaten Bandung Barat \\ Pos-el: tsanynurfajriani@gmail.com
}

\begin{abstract}
Abstrak
Penelitian ini bertujuan untuk mendeskripsikan: (1) struktur cerita dalam novel Marjanah; dan (2) citra dan stereotip perempuan Sunda dalam novel Marjanah. Metode yang digunakan dalam penelitian ini adalah metode deskriptif analitik dengan menggunakan teknik telaah pustaka dan fokalisator. Sumber data yang digunakan adalah novel Marjanah karya S. Djojopuspito. Hasilnya, terdapat: (1) tema dalam novel Marjanah yaitu tentang kritik sosial terhadap keadaan jenis kelamin (laki-laki dan perempuan) yang tidak saling menghargai. Alurnya berurutan, saling berhubungan antara bagian awal, tengah, dan akhir. Latar dalam novel ini berkisah di perkampungan dan perkotaan, latar waktu yang digunakan lebah banyak waktu faktual. Karakter yang ada dalam novel ini ada 30 nama, sedangkan sifatnya ada yang pintar, kuat, malas, kritis, setia, dll; (2) citra dan stereotip perempuan yang muncul dari novel ini adalah tokoh perempuan priyayi yang mengenyam pendidikan memiliki citra positif, stereotip baik, pintar, kuat, kritis, dan cerdas. Tokoh perempuan priyyi yang tidak mengenyam pendidikan memiliki citra positif dalam pandangan kaum jelata, tapi negatif dalam pandangan lelaki priyayi. Stereotip dalam pandangan rakyat jelata, perempuan priyayi baik, pintar, dan tinggi derajatnya, tapi dalam pandangan lelaki priyayi, lemah, hanya untuk kebutuhan seks, hanya untuk mengurus urusan rumah tangga. Tokoh perempuan jelata yang tidak mengenyam pendidika citranya negatif, stereotipnya lemah, hina derajatnya, dan hanya untuk memenuhi kebutuhan seks.
\end{abstract}

Kata Kunci: citra, stereotip, perempuan, struktural, feminisme

\section{THE IMAGE AND STEREOTIPE OF SUNDANESE WOMEN IN MARJANAH NOVEL MANUSCRIPT BY S. DJOJPUSPITO (Structural Research and Feminism)}

\begin{abstract}
This study aims to describe: (1) structure of story and (2) the image and stereotype of Sundanese women in Marjanah Novel. The method used in this study is the descriptive analysis method by using library techniques and focalist method. The data used obtain from Marjanah novel written by S.Djojopuspito. The results found are: (1) Marjanah Novel theme criticize social condition of gender (men and women) who didn't respect each other. Sequential storyline, each plot connected between the beginning, the middle until the end section. The background of this novel was set in village near countryside, mostly in factual time. The novel has 30 main character names with different characteristic such as smart, forceful, weak, generous, loyal, etc; (2) images and stereotypes of women found the thoughts of educated women have a positive image, good stereotypes, smart, strong, critical, and intelligent. Noble women figure who got positive image respect from common people but disrespected by conglomerate. From common people view, she was smart, kind and has high profile, but in conglomerate view, she was so weak, full of desire, and only
\end{abstract}


house worker. Pauper figure without educational background has negative image which stereotype is weak, vile, and only lust needs.

Key words: images, stereotype woman, structure, feminism

\section{PENDAHULUAN}

Mengkaji masalah citra dan stereotip perempuan Sunda dalam teks sastra, tidak akan lepas dari kehidupan nyata, karena teks sastra merupakan cermin dari kehidupan tersebut (Teeuw, 2013, hal. 168). Artinya, apa yang terjadi dalam isi cerita, merupakan hasil refleksi pengarang dalam menghadapi kehidupan yang sebenarnya. Begitu juga dengan gambaran tokoh-tokoh yang hidup dalam teks sastra, merupakan gambaran dari manusia-manusia yang hidup dengan pengarangnya.

Teks sastra yang akan dibahas dalam tulisan ini berbentuk novel, yang berjudul Marjanah (bc: Maryanah) karya Suwarsih Djodjopuspito. Novel Marjanah dipilih berdasarkan pada beberapa hal diantaranya adalah kepentingan penelitian feminisme ideologis, terutama tentang citra dan stereotip perempuan dalam karya sastra.

Selain ditulis oleh perempuan (sarat dalam kritik ideologis), novel Marjanah berkisah tentang kehidupan Marjanah semenjak kecil sampai dewasa. Gambaran tentang citra dan stereotip begitu tergambar dalam perjalan hidup Marjanah. Tentu bukan hanya kehidupan Marjanah saja yang diceritakan dalam novel ini, perempuanperempuan lainnya juga diceritakan dengan jelas. Novel ini jadi menarik ketika citra dan stereotip perempuan yang ada di dalamnya dilukiskan dengan hasil pengaruh alam pikiran modern. Padahal pada masa tersebut (melihat titimangsa, novel ini ditulis tahun 1937), alam pikiran perempuan masih dibayangi dengan masalah adat dan tradisi.

Untuk membahasa masalah citra dan stereotip perempuan dalam novel
Marjanah, tentu dibutuhkan pendekatan, dalam hal ini teori. Teori yang berkaitan dengan kajian tentang perempuan adalah teori feminis. Secara etimologi feminisme berasal dari kata femme (woman), yang berarti perempuan yang berjuang merebut hak kaum perempuan sebagai kelas sosial (Ratna, 2012, hal. 184).

Menurut Humm (Isnéndés, 2004 hal. 5) secara umum feminisme merupakan ideologi pembebasan perempuan. Hal itu berangkat dari keyakinan bahwa perempuan selalu mengalami ketidakadilan karena jenis kelaminnya.

Cakupan tiori feminis sangat luas, menurut Ratna (2012, hal. 184), dalam cakupan luas, feminisme mempunyai arti gerakan perempuan untuk nolak semua hal yang berkaitan dengan penindasan terhadap perempuan baik dalam bidang politik dan ekonomi atau bidang kehirupan sosial. Dalam arti sempit, yaitu dalam dunia sastra feminisme membahas dan menelaah karya sastra, baik yang berkaitan dengan proses produksi (cipta karya sastra berdasarkan jenis kelamin) atau juga berkaitan dengan resepsi. Dalam pandangan sastra, keilmuan feminisme disebut juga dengan kritik sastra feminisme (KSF).

Menurut Rutven (Isnéndés, 2004, hal. 6), KFS diharapkan mampu membuka pandangan baru, terutama yang berkaitan dengan bagaimana karakterkarakter perempuan diwakili dalam sastra. KSF menelusuri bagaimana kaum perempuan direpresentasi dan bagaimana teks terwujud dengan relasi gender dan perbedaan sosial yang ada.

KSF juga membicarakan bagaimana perempuan dilukiskan dan 
bagaimana potensi perempuan diketengahkan di tengah kekuasaan patriarki di dalam karya sastra.

Menurut Hall (Jupriono dan Supsiadji, 2011, hal. 42) bahasan KSF terbagi dalam beberapa kajian yaitu: (1) Kritik ideologis, yang meneliti stereotipe dan kesalahpahaman tentang wanita dan sebab- sebab mengapa wanita tidak diperhitungkan dalam sastra; (2) Pengkajian tentang penulis wanita, yakni sejarah karya, gaya penulisan, tema, genre, dan struktur penulisan sastrawan wanita; (3) Kritik sastra feminis sosialis, yang mengkaji tokoh wanita dalam sastra menurut perspektif ketimapangan kelas di masyarakat yang menempatkan perempuan sebagai kelas tertindas; (4) Kritik sastra feminis psikoanalitis, yang meyakini bahwa pembaca wanita lazim mengidentifikasikan diri pada si tokoh wanita yang dibacanya; (5) Kritik feminis lesbian, yang hanya mengkaji penulis dan tokoh wanita, dan berusaha mencari kepastian diri tentang konsep dasar lesbianisme.

Melihat masalah-maslaah di atas, selanjutnya mengundang rasa penasaran peneliti, untuk membahas dan menganalisis bagaimana citra dan stereotip perempuan dalam kehidupan masyarakat Sunda.

Namun yang menjadi bahasan dalam penelitian ini bukan hanya masalah citra dan stereotip perempuan saja, melainkan juga akan membahas unsur struktur yang membangun novel tersebut. Hal itu dilakukan karena premis bahwa sastra tidak bisa dilepaskan dari strukturnya. Oleh sebab itu, terbilang penting untuk membahas unsur struktur dalam novel Marjanah.

Teori struktur yang digunakan dalam penelitian ini adalah teori struktur Robert Stanton. Menurut Robert Satanton (2012, hal. 45), struktur cerita dibagi menjadi tiga bagian, yaitu: 1) tema, 2) fakta cerita (latar, alur, dan karakter), 3) sarana-sarana (judul, sudut pandang, jeung simbolisme).

\section{METODE PENELITIAN}

Metode yang digunakan dalam penelitian ini adalah metode deskriptif analitik yang berfungsi untuk menggambarkan dan memberikan pemahaman mengenai fakta-fakta yang ada dalam objek penelitian (Ratna, 2012 hal 53). Tidak hanya untuk menggambarkan, tetapi juga untuk menganalisis dengan cara meneliti relasi antara data (fakta), yang tersembunyi dalam data (fakta). Sedangkan yang menjadi relasi dalam data ini bersifat kausalitas atau sebab-akibat (il. Faruk, 2012, hal 25).

Fakta-fakta yang dimaksud dalam penelitian ini adalah data mengenai struktur cerita, citra dan stereotip perempuan yang ada dalam novel Marjanah. Sedangkan citra dan stereotip yang diteliti berkaitan dengan perilaku dan kejiwaan tokoh dalam novel.

Untuk meneliti atau menganalisis data, penelitian ini menggunakan kajian struktural dan feminisme, khususnya feminisme dalam kritik idiologi, sedangkan kajian feminisme membahas persoalan kritik idiologi yang secara khusus meneliti citra dan stereotip perempuan dan sebab mengapa perempuan 'dipandang sebelah mata' oleh lelaki.

Teknik penelitian yang digunakan adalah teknik fokalisator dan teknik interpretasi. Untuk mengumpulkan semua data teknik yang digunakan adalah teknik studi pustaka.

Data dalam penelitian ini adalah struktur cerita serta citra dan stereotip permpuan yang bersumber dari novel Marjanah karya S. Djojopuspito. Novel ini pertama kali ditulis pada tahun 1937, hanya saja baru dicetak oleh Balai Pustaka pada tahun 1959.

\section{HASIL DAN PEMBAHASAN}

Hasil dan pembahasan dalam penelitian ini meliputi (1) struktur novel dan (2) citra dan stereotip perempuan 
Sunda. Struktur novel yang ditemukan dalam novel ini meliputi tema, fakta cerita (alur, karakter, dan latar), dan sarana-sarana sastra (judul, sudut pandang, dan simbolisme).

Citra dan stereotip yang ditemukan, meliputi citra dan stereotip tokoh perempuan priyayi yang mendapatkan pendidikan, tokoh perempuan priyayi yang tidak mendapatkan pendidikan dan tokoh rakyat jelata yang mendapatkan pendidikan.

Lebih jelasnya, hasil analisis struktur dan citra serta stereotip perempuan dalam novel Marjanah karya S. Djojopuspito dijelaskan di bawah ini.

\section{Struktur Cerita Novel Marjanah}

Bahasan struktur cerita novel Marjanah meliputi tema, fakta cerita, dan sarana sastra.

\section{Tema}

Menurut Stanton (2012, kc. 36) tema merupakan aspek cerita yang sejajar dengan makna penting dari pengalaman manusia yang terus. Tema sendiri mempunyai kekuatan dan menegaskan hubungan antar kejadiankejadian yang diceritakan sampai menjadi sebuah ceita yang kokoh.

Tema yang diangkat dalam novel Marjanah, mengenai kritik terhadap keadaan sosial yang tidak saling menghargai, dan terhadap keadaan jenis kelamin (laki-laki dan perempuan) yang tidak saling menghargai, terutama dalam kehidupan rumah tangga.

Gagasan tersebut terus-menerus diceritakan dalam setiap peristiwa dan kejadian yang dialami oleh setiap tokoh dalam cerita ini. Seperti yang tergambar dalam beberapa kejadian yang ditemukan di bawah ini.

a. Si Pinuk dipermainkan oleh anak yang ada di kampungnya karena dianggap gila, Tetapi Marjanah tetap mengakui, menemani, dan menyayangi $\mathrm{Si}$ Pinuk sebagai sahabatnya. b. Marjanah yang berstatus priyayi, sedangkan Bapak Supi yang berstatus miskin, tidak menjadi penghalang Marjanah untuk bergaul dengan Bapak Supi. Perbedaan status sosial tidak menjadikan Marjanah sombong atau menghina Bapak Supi. Justru sebaliknya, Marjanah menunjukkan sikap yang sangat menghargai Bapak Supi.

c. Perceraian antara Sulaeha (Ibu Marjanah) dan Ayah Marjanah disebabkan oleh perempuan lain. Dalam hal ini, Ayah Marjanah tidak menghargai istrinya. Ayah Marjanah lebih memilih untuk mendua.

d. Persahabatan Marjanah dengan Jack yang tidak terhalang oleh persoalan jenis kelamin. Marjanah dan Jack sangat erat, mereka terbuka dalam setiap masalah dan tidak pernah menyembunyikan masalah apapun.

e. Pertengkaran Marjanah dan Jack disebabkan oleh sikap Jack yang berubah. Perubahan sikap Jack terjadi karena Jack pernah melakukan kesalahan terhadap perempuan (dalam hal ini Jack tidak menghargai perempuan), apalagi Jack merasa cemburu kepada Sutrisna karena menyukai Marjanah. Merasa tidak dapat menerima hal itu, Jack lalu menyangka yang tidak-tidak kepada Marjanah.

f. Marjanah dan Jack saling memaafkan atas segala kesalahan mereka. Sikap keduanya yang pemaaf, menegaskan bahwa mereka tidak saling menyalahkan. Mereka bersahabat kembali.

g. Marjanah menyukai Sutrisna, Begitu juga Sutrisna menyukai Marjanah. Tetapi, karena terhalang oleh aturan adat dan kebiasaan masyarakatkarena Sutrisna masih sebagai suami Martilah-mereka tidak mengikuti hawa nafsu untuk hidup bersama. Mereka lebih memilih untuk berpisah, meskipun berat untuk keduanya. Dalam hal ini, Marjanah atau pun 
Sutrisna memiliki sikap saling menghargai terhadap sesama.

h. Jack menyukai Marjanah, tetapi Marjanah menolaknya. Meskipun ditolak, Jack tetap menghargai Marjanah.

i. Martilah menyukai Jack dan mengatakan perasaannya secara langsung kepada Jack. Tetapi Jack sadar bahwa Martilah telah bersuami, yaitu Sutrisna, sahabatnya. Kesadaran Jack menandakan bahwa Jack memiliki sikap saling menghargai terhadap sesama.

j. Nyi Sati menikah dengan Bang Amat. Tetapi tidak berlangsung lama, karena Bang Amat telah memiliki perempuan lain. Menghadapi perselingkuhan Bang Amat, akhirnya Nyi Sati juga berselingkuh dengan lelaki lain, lalu memilih untuk pergi dari rumah bibinya. Peristiwa ini menandakan bahwa keduanya tidak saling menghargai antar sesama. Bang Amat menganggap Nyi Sati hanya untuk memenuhi kebutuhan birahinya saja. Sedangkan Nyi Sati yang telah merasa disakiti tidak menerima keadaannya, akhirnya Nyi Sati melakukan hal yang sama, yaitu berselingkuh.

k. Nyi Sati menjadi nyai di rumah orang Belanda. Statusnya tanpa perkawinan, tetapi tinggal di rumah can Reewijk. Hal ini bukan hanya menunjukkan hubungan antara lelaki dan perempuan, tetapi lebih dari itu, hubungan antara pribumi sebagai pihak yang dijajah dan orang Belanda sebagai penjajah. Meskipun van Reewijk adalah orang Belanda yang menjajah Nusantara, tetapi memberikan perlakuan yang baik terhadap Nyi Sati. Nyi Sati ditempatkan di tempat yang baik dan diberi kemewahan, tetapi van Reewijk tidak menikahi Nyi Sati.

1. Mian diusir oleh Nyi Sati. Mian adalah kakak kandung Nyi Sati, tapi ketika Mian menemui Nyi Sati, Mian diusir dan dimarahi, dianggap maling. Hal itu terjadi karena Nyi Sati merasa sombong akan statusnya yang "mendadak' menjadi seorang priyayi, tidak mau diganggu oleh kakaknya yang miskin.

m. Martilah menikah dengan Jack, Sedangkan Marjanah menikah dengan Sutrisna.

Dari penjabaran di atas, dapat disimpulkan bahwa peristiwa dan kejadian tersebut salih berhubungan dan menjadi satu kesatuan alur cerita yang utuh. Maka dari itu, tema atau gagasan yang ada di dalam novel ini, berkaitan dengan kritik terhadap keadaan masyarakat yang tidak saling menghargai.

\section{Fakta Cerita}

Fakta cerita dalam pembahasan novel ini meliputi alur, karakter, dan latar.

\section{Alur}

Alur adalah rangkaian peristiwa dalam sebuah cerita. Istilah alur dibatasi dengan peristiwa dan kejadian yang saling berkaitan secara kausal. Peristiwa kausalitas merupakan rangkaian peristiwa saling berkaitan dan berpengaruh (Stanton, 2012, hal. 26).

Alur dalam novel ini tidak hanya saling berkaitan antara peristiwa satu dengan yang lainnya, tetapi juga memenuhi syarat bagian awal, tengah, dan akhir. Apabila di bagi menjadi beberapa bagian, bagian awal dalam alur ini merupakan alur kehidupan Marjanah di kampung ayahnya., yaitu ketika Marjanah masih kecil. Bagian kedua, ketika Marjanah mulai remaja. Peristiwa ini dialami Marjanah ketika tinggal di Bandung, di rumah Sulaekin. Sedangkan alur bagian akhir, ketika Marjanah sudah mengenal urusan cinta sampai Marjanah dilamar oleh Sutrisna.

Konflik yang terlihat dalam novel ini lebih kepada konflik batin. Hal 
tersebut ditandai oleh beberapa peristiwa yang dialami oleh setiap tokohnya. Misalnya perceraian Sulaeha dan suaminya, pertengkaran antara Marjanah dan Jack atau kegelisahan hati Marjanah, Jack, Sutrisna, dan Martilah yang menjadi klimaks dalam alur novel Marjanah.

Konflik batin yang dipilih oleh pengarang tentu sesuai dengan gagasan pengarang. Untuk membangun kesadaran tentang saling menghargai antara jenis kelamin, penggunaan konflik batin sangatlah sesuai. Tetapi sayangnya dalam konflik batin yang terjadi tidak sampai menciptakan hal yang di luar dugaan.

Alur dalam novel ini mudah ditebak bagaimana akhir ceritanya. Selain itu, beberapa alurnya kurang meyakinkan.

\section{Karakter}

Karakter terbagi menjadi dua konteks, yaitu: (1) mengarah pada individu-individu (nama) yang muncul dalam cerita; (2) mengarah pada tingkah laku yang memunculkan kepentingan, keinginan, emosi, dan prinsip moral individu-individu yang ada dalam cerita tersebut (Stanton 2012, hal. 33).

Terdapat 30 tokoh dalam novel ini, yaitu Marjanah, Bapa Supi, Sati, Mian, Ma Supi (Minah), Si Pinuk, Pak Ahim, Pak Marsid, Bapak Mirsa, Ibu Marjanah (Sulaeha), Ayah Marjanah, Nyi Sumarni, Nenek Marjanah, Kakek Marjanah, Unah, Djupri, Sulaekin, Sutirin, Suidrajat (Jack), Marto, Marno, Sutrisna, Martilah, Sumarni, Rusmali, Bang Amat, Bang Amin, Pak Mursid, Tan Kim Lek, jeung van Reewijk.

Tapi tidak semua tokoh menjadi pusat dalam cerita, ada beberapa tokoh yang hanya menjadi pelengkap, ada juga tokoh yang menjadi pusat cerita dalam novel ini. Tetapi yang menarik adalah pemilihan nama tokoh oleh pengarang yang terasa modern dan tradisional serta tokoh miskin dan tokoh priyayi.
Misalnya tokoh Marjanah, Martilah, Jack, dan Sutrisna merupakan gamparan nama tokoh modern. Mian, Supi, Sati, Sutirin, Sulaeha, merupakan gambaran nama tradisional.

Begitu juga dalam hal membentuk karakter tokoh yang mirip tetapi bertolak belakang. Tentu menguatkan tema dan peristiwa yang disampaikan dalam novel ini. Misalnya tokoh Marjanah bertolak belakang dengan Martilah, tokoh Sutrisna bertolak belakang dengan tokoh Jack, dan tokoh Sulaeha yang bertolak belakang dengan Nyi Sati.

Tokoh-tokoh yang dirancang oleh pengarang merupakan gambaran dari keadaan masa kolonial. Apalagi jika melihat keadaan saat itu, ada kaum miskin dan priyayi, ada juga yang mendapatkan pendidikan dan yang tidak mendapat pendidikan, serta ada yang modern dan tradisi.

\section{Latar}

Latar merupakan lingkungan yang melingkupi kejadian-kejadian dalam cerita. Latar dibagi tiga, yaitu latar tempat, latar waktu, dan latar sosial (Stanton, 2012, hal. 35).

Latar tempat yang membangun novel Marjanah adalah pekampungan dan perkotaan. Dua latar yang berbeda, tetapi sebagai gambaran dari situasi sosial yang berbeda.

Oleh sebab itu dapat diartikan bahwa pekampungan dipandang sebagai situasi yang mewakili kaum miskin, kaum tradisional, dan kaum yang tidak mendapatkan pendidikan. Sedangkan perkotaan dipandang sebagai situasi yang mewakili kaum priyayi, modern, dan mendapatkan pendidikan.

Latar yang menunjukkan waktu, lebih banyak yang menunjukkan waktuwaktu faktual seperti hari, minggu, bulan, dan tahun. Sedangkan latar sosial dalam novel ini tidak banyak ditunjukkan, karena banyak menceritakan masalah keluarga. 


\section{Sarana Cerita}

Sarana cerita dalam pembahasan novel ini meliputi judul, sudut pandang, dan simbolisme.

\section{Judul}

Judul merupakan representasi atau gambaran umum dari isi cerita (Stanton, 2012, hal. 35). Pembaca dapat membayangkan isi cerita dari judul. Oleh sebab itu, ada pertimbanganpertimbangan tertentu yang dilakukan pengarang dalam menentukan judul. Begitu juga dalam novel karangan Djojopuspito yang berjudul Marjanah.

Melihat isi dari cerita novel Marjanah, menceritakan tentang kehidupan Marjanah dari kecil hingga dewasa.

Marjanah bukan hanya sekedar judul sebuah novel, tetapi juga merupakan gambaran atau gagasan pengarang yang memiliki keinginan melaean dan memberi pandangan bahwa perempuan harus sadar akan posisinya. Untuk menyadari hal itu, perempuan harus mendapatkan pendidikan.

\section{Sudut Pandang}

Sudut pandang adalah visi pangarang atau disebut juga pandangan pengarang dalam melihat suatu peristiwa. Sudut pandang sendiri dibagi menjadi empat, yaitu orang pertamautama, orang pertama-sampingan, orang ketiga-terbatas, dan orang ketiga-tidak terbatas (Stanton, 2012, hal. 53-54). Dalam novel Marjanah, Suwarsih sebagai pengarang menggunakan sudut pandang orang ketiga-tidak terbatas.

Pengarang memposisikan diri sebagai pengatur seluruh karakter. Hal ini ditandai oleh pelaku utama yang terus-menerus namanya disebut. Sedangkan yang paling jelas terlihat dari judul, Marjanah. Hal ini menandakan bahwa pengarang ada dalam posisi orang ketiga-tidak terikat.

\section{Simbolisme}

Simbolisme adalah wujud detaildetail konkret dan faktual dan memiliki kemampuan gagasan dan emosi dalam pikiran pembaca (Stanton, 2012, hal. 64). Dalam novel Marjanah hanya ditemukan satu simbolisme yaitu ketika peristiwa Sutrisna dan Marjanah berada di taman bunga, mereka sama-sama mengungkapkan cinta meraka dengan menggunakan kata bunga. Bunga menjadi simbolisme dalam novel ini.

\section{Citra dan Stereotip Perempuan Sunda dalam Novel Marjanah}

Bentuk citra dan stereotip perempuan dalam novel Marjanah terbagi menjadi tiga, yaitu: 1) tokoh perempuan priyayi yang tidak mengenyam pendidikan; 2) tokoh perempuan miskin yang tidak mengenyam pendidikan; dan 3) tokoh perempuan priyayi yang mengenyam pendidikan.

\section{Tokoh priyayi yang mengenyam pendidikan}

Citra dan stereotip perempuan golongan priyayi awal abad-20 bisa disebut mempunyai dua gambaran yang berbeda. Gambaran tersebut tergantung pada mengenyam pendidikan atau tidaknya. Secara umum memang golongan perempuan priyayi sangat dihormati dan dihargai, tapi hal tersebut hanya terjadi ketika berhadapan dengan golongan miskin (baik laki-laki maupun perempuan).

Keedaan di atas tergambar dalam novel Marjanah. Tokoh Sulaeha yang status sosialnya priyayi, sangat dihargai dan dihormati oleh golongan miskin yang ada di kampungnya, terutama oleh Bapak Supi dan Mak Supi. Tapi hubungan golongan perempuan priyayi dan golongan lelaki priyayi sangat berbeda.

Lelaki priyayi umumnya memandang perempuan (baik priyayi maupun miskin yang tidak mengenyam pendidikan) hanya untuk memenuhi 
napsu saja, lemah, hina, setia (atau lebih tepatnya taat pada lelaki) atau dalam arti lain laki-laki lebih berkuasa dari pada perempuan.

Hubungan antar laki-laki dan perempuan sifatnya hierarki, yaitu lelaki lebih dominan, lelaki yang menentukan, perempuan harus taat pada laki-laki. Karena perempuan harus taat pada lakilaki, perempuan selaki makhluk hirup menjadi tidak memiliki kabebasan untuk menentukan dan memilih segala keinginannya. Perempuan sangat terikat oleh citra dan stereotip sebagai perempuan (Rizqi, 2014, hal.273 ).

Keadaan di atas tidak hanya dirasakan oleh Sulaeha sebagai tokoh sastra, tapi juga dialami oleh perempuan pada umumnya dalam kehidupan nyata.

Banyak kasus poligami dan perceraian yang terjadi oleh golongan perempuan priyayi - terutama yang tidak mengenyam pendidikan formal-jadi gambaran nyata. Menjadi masalah selanjutnya, poligami dan perceraian antara suami dan istri dikalangan golongan priyayi bisa terjadi secara sepihak, yaitu oleh pihak lelaki. Lakilaki juga bisa seenaknya menceraikan istrinya, tanpa berdiskusi dulu.

Misalnya yang dialami oleh istri Bupati Wirahadiningrat. Karena Bupati Wirahadiningrat mempunyai keinginan untuk menikah lagi dengan perempuan lain, maka ia terpaksa menceraikan istrinya.

Hal serupa dialami oleh istri R.A.A. Wiranatakusumah V, yang diceraikan sepihak dengan cara mengirim pesan telegram kepada mertuanya (Lubis, 1998, hal. 236).

Keadaan diatas hampir sama dengan cerita Sulaehan dalam novel Marjanah. Sulaeha secara sepihak diceraikan oleh suaminya. Adapun yang menjadi alasannya, adalah suaminya tergoda oleh perempuan lain.

"Ayeuna mah Eulis, jeung dipukpuk ku kasedih mah, ku timbangan engkang, mending mulih baé ka tuang rama" (Djojopuspito, 1959, hal. 36.)

("Sekarang mah Eulis, daripada diliputi kesedihan, usul Akang lebih baik pulang saja ke rumah bapakmu")

Cerai sepihak memang sudah menjadi keumuman golongan lelaki priyayi. Tapi keadaan yang dialami oleh Sulaeha sangat menyengsarakan. Apa yang dilakukan oleh suami Sulaeha, sama sekali tidak berfikir panjang. Ia tidak memikirkan nasib anaknya. Ia juga tidak bisa melihat pada kesetiaan istrinya. Matanya seaakan tertutup oleh napsu seksnya kepada perempuan lain, yang lebih cantik.

Selain Sulaeha, tokoh priyayi yang tidak mengenyam pendidikan tergambar dalam diri Martilah. Martilah merupakan gambaran istri priyayi yang modern, yang sayangnya Martilah tidak sempat (tidak diceritakan) mengenyam pendidikan keluarga. Hal ini juga hal ogé anu ngabédakeun sikep Martilah téh.

Martilah digambarkan sebagai perempuan yang kurang baik, tidak setia, taat pada lelaki, - padahal suami Martilah sangat menghormatinyakekanak-kanakan, dan tidak sayang pada keluarga.

Ketidaksetiaan, kekanak-kanakan, dan tidak sayang terhadap keluarga digambarkan melalui cara dirinya kabur meninggalkan Sutrisna, suaminya.

"Ah, duka teuing! Sutrisna mah Jack, Sutrisna téh henteu wanieun ngalésotkeun kuring, jadi tungtungna kuring kapaksa indit, nyaéta atuh rarasaan téh siga jadi bangbaluh $k a$ batur." (Djojopuspito, 1959, hal. 123).

(Ah, saya tidak tahu! Sutrisna mah Jack, Sutrisna tidak berani menceraikan saya, jadi akhirnya saya terpaksa kabur, begitulah perasaan ini seperti menjadi keluhan terhadap orang lain )

\section{Perempuan miskin yang tidak mengenyam pendidikan}

Perempuan Sunda kaum miskin yang tidak mengenyam pendidikan 
dalam novel Marjanah terwakili oleh tokoh Sutirin dan Nyi Sati. Citra dan stereotip perempuan miskin yang terbentuk dalam masa kolonial sangat negatif.

Banyak perempuan miskin yang mengalami ketidakadilan dan tertindas oleh golongan laki-laki. Banya perempuan miskin yang diamangpaatkan oleh Bangsa Belanda. Adapun pemanfaat ini berkaitan dengan tubuhnya. Bahkan ada sebutan khusus untuk perempuan yang hidup bersama orang Belanda, yaitu Nyai.

Hal di atas tergambar juga dalam novel Marjanah. Representasi dari golongan miskin yang menjadi nyai, adalah Nyi Sati. Nyi Sati merupakan teman lama Marjanah waktu kecil. Ketika umurnya sudah dewasa, Sati kemudian menjadi nyai orang Belanda yang bernama van Reewijk.

Memang Nyi Sati sangat disayangi dan dihargai oleh van Reewijk, diberi harta, diberi pembantu, dll. Meski begitu ia tidak memiliki kebebasan dalam hidup, Nyi Sati terikat oleh statusnya sebagai Nyai.

Kehidupan sebagai nyai-nyai pada masa kolonial tak ada kebebasan, pada satu sisi ia hidup satu rumah, bahkan satu kamar dengan orang Belanda, namun pada sisi lainnya ia harus menerima kenyataan ketidak jelasan status pernikahannya-nyai-nyai jarang ada yang dinikahi.

Kehidupan seperti itu menyebabkan citra nyai sangat negatif dalam pandangan masyarakat umum. Sedangkan dalam pandangan laki-laki Belanda, perempuan miskin hanya sebagai "mainan" dan hiburan diatas ranjang.

Keadaan Sati yang menjadi nyai memang bukan tanpa alasan, selain ia tidak mengenyam pendidikan formal dan non formal, Sati juga merupakan korban lelaki pribumi. Sebelum menjadi nyainyai, Sati sudah menikah terlebih dahulu dengan Bang Amat. Tapi kehidupannya dengan Bang Amat tidak berlangsung lama, hal tersebut dikarenakan Bang Amat terpikat oleh perempuan lain. Bukan hanya terpikat tapi Bang Amat juga telah mengawini perempuan tersebut. Perempuan mana yang tidak sakit jika mengetahui suaminya menak lagi dengan perempuan lain? Apalagi alasan Bang Amat menikah lagi karena "wajar".

"Ku teu boga kaéra, léwéh mani rawah-riwih. Éta mani carindul kitu, abong-abong anu céngéng. Enya akang téh boga nu anyar, tapi éta mah jamakna, da nu séjén ogé karitu. Barina ogé teu matak nyusahkeun ka manéhna, bisaeun balangsiar sorangan" (Djojopuspito, 1959, hal. 127-128).

("Tidak punya malu, menangis sampai begitu. Itu mata bengkakmu, dasar cengeng. Iya akan punya istri baru, tapi hal itu wajar, yang lain juga begitu. Lagian tidak menyusahkan kamu kok")

Tampak begitu mudahya Bang Amat menyebut "céngéng" dan "wajar". Hal tersebut tentu menjadi tanda bahwa Bang Amat tidak menghargai dan menghormati isrtinya. Bang Amat memandang perempuan hanya sekedar pemenuhan kebutuhan naps saja. Tidak memandang sebagai manusi yang harus dinilai.

Selain Nyi Sati, tokoh miskin lainnya yaitu Sutirin. Sutirin tidak pernah mengenyam pendidikan formal sakola, tapi Sutirin mengenyam pendidikan non formal dari indungnya. Meski citra dan stereotipnya sama, yaitu lemah, hanya mengurusi rumahtangga, dan tradisional, tapi Sutirin mempunyai gambaran yang berbeda dengan Nyi Sati. Sebagai mana yang disampaikan langsung oleh pangarangna.

Sutirin istri basajan, pangartina sedeng, rupana jajar pasar. Dina pasamoan mah tangtu moal aya nu ngawaskeun Sutirin, sabab kacida lungguhna, katutup ku nu séjénna, tapi dina kapercékaanana mah, hésé kaéléhkeunana. Dina perkara bumén- 
bumén atawa prakna digawé di dapur, hésé néangan bandingna. Éstuning anu kacipta ku istri kuno téa, nya éta: hadé haté, henteu loba omong nurut ka ibu. (Djojopuspito, 1959, hal. 53)

(Sutirin perempuan yang bersahaja, pengetahuannya sedang, muka pasar. Dalam pertemuan tentu ia tidak akan menjadi pusat perhatian, sebab Sutirin sangat lugu, tertutup oleh yang lain tetapi dalam keterampilan susah dikalahkan. Dalam masalah rumah tangga atawa bekerja di dapur, susah mencari bandingannya. Tentu yang tercipta oleh perempuan kuno, yaitu: baik hati, tidak banyak bicara, taat pada ibu.)

Melihat kutipan di atas, gambaran Sutirin sama dengan Sulaéha, meski bukan priyayi tapi mengenyam pendidika non formla, Sutirin téh digambarkeun pendiam tapi terampil dalam urusan rumah tangga, dan terutama baik hati. Artinya bagi pengarang mengurusi rumah tangga itu bukan citra dan stereotip yang hina, begitu juga menjadi istri yang tradisional kuno bukan berarti nandakeun perempuan itu tidak binangkit.

\section{Tokoh Priyayi yang Mengenyam Pendidikan}

Marjanah menjadi tokoh inti dalam novel ini. Bukan karena sebagai judul novelnya, tetapi karena marjanah merupakan gagasan pengarang tentang bagaimana menjadi perempuan yang "ideal' dalam kehidupan bermasyarakat, terutama dalam keluarga.

Sebagai perempuan, Marjanah sangat dihargai dan dihormati oleh sesama, lelaki atau perempuan, miskin atau priyayi. Sejak kecil Marjanah juga sangat dihargai dan disayangi. Marjanah dihargai bukan hanya karena keturunan priyayi, tetapi juga karena Marjanah mengenyam pendidikan non formal dari ibunya.

Pikeun umur duabelas taun mah Marjanah téh kacida leleb rasana, surti nyirikeun polah nu séjén, kawantu hadé didikan téa. Ti leuleutik Marjanah tara dipercayakeun ka bujang, tapi sagalagalana diurus ku ibuna. Keur mah titadina boga watek seukeut tingal, beuki leleb baé ngarasakeunnana sagala kereteg haté téh Marjanah mah (Djojopuspito, 1959, hal. 15).

(Untuk anak berumur duabelas tahun, Marjanah memiliki perasaan yang dalam, mengerti akan perilaku orang lain, apalagi dididik dengan baik. Sejak kecil Marjanah tidak pernah diasuh oleh orang lain, Marjanah hanya dididik oleh ibunya. Dari awal Marjanah sudah menjadi anak yang peka, semakin dalam saja Marjanah dalam urusan merasaan perasaan).

Pendidikan dalam keluarga sangat penting untuk membentuk karakter manusia yang baik hati dan peka. Hal tersebut tidak hanya dirasakan oleh ibu atau keluarga, tetapi dirasakan juga oleh masyarakat di sekitarnya.

Sebaliknya, apabila tidak mengenyam pendidikan dari keluarga atau seorang ibu, karakter yang muncul akan kurang baik. Karakter ini kemudian akan memunculkan citra negatif sebagaimana dicontohkan oleh tokoh Martilah dan Nyi Sati.

Marjanah tidak hanya mendapatkan pendidikan dari keluarga, tetapi juga mengenyam pendidikan formal di sekolah. Hasinya, Marjanah tidak hanya menjadi pribadi yang baik hati dan ramah, tetapi juga pintar, kritis, dan modern. Dapat disimpulkan bahwa pendidikan keluarga dapat menghasilkan jiwa dan hati yang baik, sedangkan pendidikan formal menghasilkan pola fikir Marjanah yang kritis, cerdas, dan modern. Karakter Marjanah tersebut akhirnya membangun citra dan stereotip perempuan yang mengenyam pendidikan.

Citra dan stereotip Marjanah tersebut menjadi berarti untuk Jack. Jack sangat menghormati dan menghargai Marjanah, sehingga Jack berjanji kepada 
Marjanah, bahwa Jack tidak akan melakukan hal yang buruk.

"Marjan, ti ayeuna kuring niat jadi jalma bener. Emh, Mar sajagat ieu lamun dipénta $k u$ anjeun, hamo dikorétkeun. Keun baé, anjeun tresna ka Sutrisna ogé, kuring mah arék sabar baé. Asal Maryan ulah miceun, daék miroséa ka nu hina. Duh Mar, kakasih kuring, lamun kuring bisa ngaganti kanyeri anjeun mah, kajeun kudu masrahkeun nyawa sorangan ogé, tangtu dibélanana. Tapi ayeuna, kuring arék ngadagoan nepi ka Marjan sorangan neundeun katresnaan ka kuring..." (Djojopuspito, 1959, hal. 81).

("Marjan, mulai dari sekarang saya akan menjadi orang yang lebih baik. Emh, Mar, jika seluruh dunia ini kamu pinta, akan saya berikan meskipun nyawa taruhannya. Tapi sekarang, saya akan menunggu sampai Marjan sendiri mencintai saya...")

Rasa hormat Jack kepada Marjanah tidak hanya dalam ucapan, tetapi juga perilaku. Jack yang awalnya tidak menghargai perempuan, dengan adanya Marjanah, fikiran dan perilaku Jack berubah. Jack sadar bagaimana cara memposisikan diri dan berhadapan dengan perempuan.

Tapi, sakitu gedéna gogoda, Jacky teu weléh inget ka Trisna.

"Kumaha sobat kuring?" Pikir Jacky.

Tungtungna leungeun téh rada loncér tina cangkéng nu dicekel, rarasaan asa keueung, asa tiis, asa hémeng, ku naon tadi mani ngentabngentab ku birahi, bet tuluyna ras inget deui ka Marjanah, ras kana jangji keur basa ngiuhan di handapeun tangkal manggu. Martilah tanggah, neuteup kana beungeut Jacky, anu marahmay siga nu suka-bungah.

"Aya naon, Jack?" Martilah rada kagét, sabab Jacky paromanana biasa deui, henteu siga tadi kawas nu kakurung ku kabirahian.
"Marti! Geuning plong baé haté téh ayeuna mah! Ya Allah méhméh baé kuring poho kana jangji..." (Djojopuspito, 1959, hal. 103).

(Tapi, meskipun godaannya besar, Jacky tetap ingat pada Trisna. Jacky."

"Bagaimana sahabat saya?" Fikir

Akhirnya tanganya lepas dari pinggang yang dipeluknya, perasaanya sedikit takut, sedikit dingin, sedikit heran, mengapa tadi seperti terbakar, tapi kemudian ingat lagi ke Marjanah, kemudian ingat lagi pada janji ketika berteduh di bawah pohon mangu. Martilah tengadah, menatap muka Jack, yang bahagia.

"Ada apa Jack?" martilah kaget, sebab raut muka Jack kembali biasa, tidak tampak terkungkung napsu

"Marti! Sekarang saya sudah lega! Ya Allah hampir saja saya lupa pada janji

Dari kejadian di atas Jack sudah memandang perempuan melalui kacamata yang beda. Perempuan itu harus dihargai dan dihormati, meskipun perempuan tersebut kurang baik dan suka mengumbar napsu. Berubahnya sikap Jack dikarenakan pertemuan Jack dengan Marjanah. Perempuan yang sangat ia hormati dan hargai, sebab baik hati, kritis, peka, dan jujur.

Tidak hanya Jack yang memandang Marjanah melalui kacamat yang beda, Sutrisnya juga sama. Terutama Sutrisnya yang menilai Marjanah karena cara berfikirnya yang beda, Marjanah sangat kritis dan cerdas.

Pandangan di atas tergambar ketika Sutrina bercakap-cakap dengan Martilah. Percakapn tersebut merupakan bentuk perbandingan antara Marjanah dengan Martilah atau antara yang mengenyam pendidikan dengan yang tidak.

"Aéh, aéh, Marti téh sirik kitu? Tangtu moal ngarti, kunaon sabab pang kuring kapincut ku Maryan, Marti mah geulis, manis, lenjang, dangah..., ari 
Maryan... jungjunan haté kuring! Tah éta bédana téh, Marti! Langit jeung lemah moal bisa disaruakeun kamulyaanana! Lemah nanggeuy sarupaning tatangkalan pikeun hirupna jelema. Langit gumebyar, disangling $k u$ sorot bulan, ngungkulan, mahluk nu paantay-antay hirupna... tah, Marti, nya kitu rarasaan kuring ayeuna téh..." (Djojopuspito, 1959, hal. 104).

("Aduh, aduh, Marti sirik? Tentu tidak akan mengerti, kenapa saya tertarik pada Marjan, marti cantik, manis, tinggi.. sedangkan Marjan pujaan hati saya! Nah itu dia perbedaannya, Marti! Langit dan bumi tidak akan bisa disamakn derajatnya! Bumi menopang pepohonan untuk kehidpan manusia. Langit mengahmpar, dihiasi oleh cahaya bulan, menyaksikan makhluk yang berdampingan hidupnya...begitulah, Marti perasaan saya sekarang.")

Sutrisna sangat menghormati perempuan yang tinggi ilmunya. Bahkan bentuk pujian untuk Marjanah dilontarkan langsung oleh Sutrisna.

Marjan! Asa ku surup kana ngaranna! Henteu layak reujeung batur! Marjan! Panon hurung, cicirén nu seukeut uteuk! (Djojopuspito, hal. 96).

(Marjan! Betapa cocok dengan namanya! Tidak layak dengan yang lain! Marjan! Mata bersinar, pertanda kritis pemikirannya!)

Intinya untuk membangun citra dan stereotip perempuan dalam pandangan lelaki, tidak ada cara selain memiliki atau mengenyam pendidikan formal dan non formal. Hal tersebut juga yang menjadi cita-cita pengarang. Dunia yang "ideal" yang saling menghargai antara jenis kelamin.

Urang mah ulah daék dijieun pangleler napsu lalaki! Urang mah kudu jadi sobat hirup, raket, dalit, jeung satia! Enyaan kitu Marjanah ngomongna téh, atawa dina biwir baé, padahal sungkan ngalampahkeunana? Marjan! Asa ku surup kana ngaranna! Henteu layak reujeung batur! Marjan! Panon hurung, ciciren nu seukeut uteuk!

(S.

Djojopuspito, hal. 96).

(Kita jangan mau dijadikan pemuas nafsu lelaki! Kita harus menjadi teman hidup, dekat, dan setia! Betul begitu kata Marjan, atau hanya ucapan saja, padahal tidak mau melakukannya? Marjan! Betapa cocok dengan namanya! Tidak layak dengan yang lain! Marjan! Mata bersinar, pertanda kritis pemikirannya!)

\section{SIMPULAN}

Membahasan citra dan stereotip perempuan dalam masyarakat Sunda tentu akan dihadapkan pada masalah yang cukup sulit, selain keterbatasan literasi tentang citra dan stereotip perempuan Sunda, masalah lainnya adalah benturan wacana budaya, terutama antara Barat dan Timur

Selain itu, terkadang pemahaman mengenai konsep féminisme Barat sering ditelan bulat-bulat, diterapkan, bahkan diikuti dengan gaya yang serupa, tanpa ada proses akulturasi, yang selanjutnya perempuan Timur ingin sama dengan perempuan Barat.

Begitu juga dengan novel Marjanah, aya sawatara hal yang sama dengan Perempuan Barat. Teutama dalam cara berfikir kritis, meskipun Marjanah turuan Priyayi dan mengenyam pendidikan tinggi, tapi ia tidak lupa pada posisinya sebagai perempuan; tidak ingin sejajar dengan laki-laki atau sampai menuntut hak-hak perempuan dalam berbagai keadaan.

Nyangking atikanna atikan formal dan non formal téh tétéla ngawangun citra dan stérétip anu béda. Lebah dieu pangarang téh saenyana hayang nepikeun gagasan yén perempuan téh kudu sakola, sangkan nasibna robah.

Penulis sadar bahwa citra dan stereotip perempuan masa kolonial sangat negatif, tapi melalui novel Marjanah, penulis mencoba untuk melawan sembari membangun citra dan strereotip perempuan yang diinginkan 
oleh penulis. Bagi penulis perempuan mengenyam pendidikan sekolah it, bukan untuk sebuah karir, tapi untuk memosisikan dirinya di masyarakat sebagai perempuan yang memiliki derajat tinggi.

\section{PUSTAKA RUJUKAN}

Djodjopuspito, S. (1969). Marjanah. Djakarta: Dinas Penerbitan Balai Pustaka.

Ekadjati, E.S. (2006). "Radén Déwi Sartika (1884-1947): Ngadegkeun sakola ngabinangkitkeun wanoja". Dimuat dina buku $\mathrm{Nu}$ maranggung dina sajarah Sunda. Bandung: PSS.

Faruk, Dr. (2012). Metode penelitian sastra sebuah penjelajahan awal. Yogyakarta: Pustaka Pelajar.

Isnéndés, R. (2004). "Suara perempuan dalam novel Sunda Puputon 'Buah Hati' karya Aam Amilia". Dimuat dina Jurnal FPBS.

Jupriono, D. jeung Supsiadji, Mateus Rudi. (2011). "Aplikasi teori strukturalisme genetik, feminisme, sastra \& politik, teori hegemoni, resepsi sastra dalam penelitian mahasiswa". Dimuat dina jurnal Faraprase, e-jurnal Parafrase Vol.11 No.01 Februari 2011.
Lubis, N.H. (1998). Kehidupan kaum ménak Priangan 1800-1942. Bandung: Pusat Informasi Budaya Sunda.

Ratna, N.K. (2012). Teori, metode, dan teknik penelitian sastra. Yogyakarta: Pustaka Pelajar.

Rizqi, S. (2014). "Tuntutan feminisme radikal terhadap sistem patriarki pada pemikiran Nh. Dini dalam karya sastranya". Dimuat dina AVATARA, e-Journal Pendidikan Sejarah. Volume 2, No. 3, Oktober 2014.

Stanton, R. (2012). Teori fiksi. Yogyakarta: Pustaka Pelajar.

Teeuw. A. (2013). Sastera dan ilmu sastera. Bandung: Pustaka Jaya.

\section{UCAPAN TERIMA KASIH}

Saya ucapkan terimakasih pada Allah Swt. yang terus memberikan nikmat sehingga makalah ini rampung dikerjakan. Terimakasih pada seluruh dosen Departemen Pendidikan Bahasa Sunda, terutama pada Dr. Dedi Koswara, M.Hum dan Dr. Retty Isnendes, M. Hum. yang memberi masukan perihal makalah ini. Terimakasih juga saya ucapkan kepada penerbit yang telah menerbitkan makalah ini. 